\title{
O ESCRITOR, O ANTROPÓLOGO E O SOBRINHO DA ONÇA ${ }^{1}$
}

\author{
THE WRITER, THE ANTHROPOLOGIST AND THE JAGUAR'S \\ NEPHEW
}

\author{
Cristiane Checchia (UNILA) \\ crischecchia@gmail.com
}

\begin{abstract}
RESUMO: O escritor argentino Juan José Saer (1937-2005) desenvolveu em alguns de seus ensaios críticos a ideia de que a Literatura seria uma antropologia especulativa. Proponho neste artigo investigar essa imagem mais a fundo, entendendo-a de certo modo literalmente e deixando os termos do campo discursivo antropológico ressoarem sobre a poética saeriana, tanto em seu entendimento sobre a linguagem como em algumas das imagens trabalhadas em sua ficção. Desenvolvo ainda essa leitura experimentando a sobreposição de olhares de uma antropologia que se nutre da literatura e de uma literatura que se vê como antropologia, por meio do cruzamento dos textos do escritor, Saer, e do antropólogo, Eduardo Viveiros de Castro, na condição de leitores de um mesmo conto de Guimarães Rosa.
\end{abstract}

PALAVRAS-CHAVE: Juan José Saer; literatura argentina contemporânea; antropologia especulativa.

ABSTRACT: The Argentine writer Juan José Saer (1937-2005) developed in some of his critical essays the idea that Literature would be a speculative anthropology. In this article I propose to investigate this image further, understanding it somewhat literally and letting the terms of the anthropological discursive field resonate over Saer's poetics, both in his understanding of language and in some of the images worked in his fiction. I also develop this reading by experimenting with the overlapping looks of an anthropology that feeds on literature and of a literature that sees itself as anthropology by crossing the texts of the writer, Saer, and of the anthropologist, Eduardo Viveiros de Castro, as readers of the same short story by Guimarães Rosa.

KEYWORDS: Juan José Saer; contemporary Argentine literature; speculative anthropology.

\footnotetext{
${ }^{1}$ Este trabalho é uma versão revista, sintetizada e atualizada de um dos capítulos de minha tese Percepção, recordação e linguagem - ensaio e ficção em El río sin orillas, de Juan José Saer, defendida em 2012 na Universidade de São Paulo.
} 


\section{Da antropologia em direção à literatura e da literatura como antropologia}

Proponho neste artigo pensar relações entre dois campos que têm estabelecido diversas pontes de aproximação de parte a parte: da antropologia em direção à literatura e da literatura em direção à antropologia. É evidente que essa reflexão entendida de modo amplo demandaria recursos de análise que não me estão disponíveis, mas busco realizá-la deixando os termos de um campo ressoarem sobre o outro, como uma maneira de nos aproximarmos da obra do escritor argentino Juan José Saer (1937-2005).

A aproximação que procurei estabelecer entre o campo antropológico e o literário dá-se no sentido de imaginar múltiplas projeções entre eles, as quais pudessem evidenciar a dimensão poética da antropologia e a dimensão antropológica da literatura. Antes do que promover esse encontro em uma esfera na qual tudo se resumiria a diferentes dimensões do discurso, optei por aproximar os dois campos pensando o modo como expressam um desejo de saber sobre o mundo, apesar de todas as dificuldades implicadas em realizá-lo.

A ideia de literatura como portadora de um conhecimento antropológico foi apenas mencionada por Saer em breves e poucas referências em seus artigos críticos e entrevistas. Ao invés de desenvolver longas teses sobre o tema, foi no próprio exercício de sua escrita que o autor forneceu elementos para explorarmos o potencial interpretativo dessa imagem.

Pretendo estender a analogia sugerida pelo autor para iluminar alguns dos núcleos mobilizadores de sua poética, afinal, se os antropólogos se apoiaram na literatura para refletir sobre o exercício da escrita antropológica, o inverso também pode ser instigante: apoiar-se em algumas questões fundamentais da antropologia para iluminar um modo de leitura e alguns dos procedimentos narrativos de um escritor de ficção.

Tal aproximação pressupõe certa arbitrariedade. Em todo olhar que cruza campos discursivos distintos tende-se a "transformar o Outro em Um quando, em verdade, há uma infinidade de vozes que o representam" (SCHWARZC, 2000, p.27), quer dizer, falamos em $a$ antropologia, como se não houvesse diferentes concepções e vertentes que desenhassem o campo, e o mesmo poderia ser dito em relação à literatura. Ainda assim, e sem desconhecer os princípios que distinguem as diversas linhas da antropologia, procuro pensar certa atitude e a curiosidade antropológicas como metáfora do narrador saeriano.

Não sem algum risco, faço operar a metáfora assumindo-a, em certa medida, 
literalmente, promovendo, na última seção deste artigo, um cruzamento entre os textos de Juan José Saer e do antropólogo Eduardo Viveiros de Castro, aproximados na condição de leitores de um mesmo conto de ficção, "Meu tio o Iauaretê", de Guimarães Rosa (1969).

Pensemos primeiramente em um horizonte de aproximação dos antropólogos em direção à literatura. Desde suas origens, ou pelo menos desde que superou os prejuízos que a uniam às ciências da natureza, a antropologia configurou-se a partir de uma curiosidade sobre as culturas como produtoras de metalinguagem, isto é, a partir do interesse voltado às formas diversas pelas quais os seres humanos em diferentes culturas pensam seu próprio pensamento (DaMATTA, 1987). Tendo isso em vista, percebe-se que os problemas em torno à linguagem constituíram desde cedo um terreno comum de investigação dos antropólogos com outros cientistas sociais e com os literatos ${ }^{2}$. Como é sabido, tais investigações tomaram enorme impulso nos anos 50 e 60 a partir dos encontros disciplinares proporcionados pelo conhecido giro linguístico nas Ciências Sociais.

Mais recentemente, porém, as relações entre os dois campos mobilizou novas questões quando alguns autores propuseram-se a investigar os mecanismos de produção de sentido e as estratégias narrativas inerentes à escrita antropológica, a partir da teoria e da crítica literárias. Para Gilles Philippe (2002, p.71), ainda que não esteja em questão a armadilha do tudo é fictício ou tudo é literário, os antropólogos passaram a enfrentar mais diretamente a dificuldade de demarcação da fronteira que divide o emprego expressivo e o emprego heurístico da ficção em seus textos, de diversos modos: sublinhando a percepção de que estratégias narrativas da ficção sempre garantiram maior poder de convencimento aos antropólogos, por um lado; por outro, buscando compreender como tais estratégias funcionaram também como recurso de análise (o uso de metáforas, a investigação de uma narrativa ou a descrição de personagens-tipo, por exemplo) $)^{3}$.

Há uma extensa bibliografia a respeito, mas os trabalhos de Clifford Geertz (2005) e de

\footnotetext{
2 Para ficarmos com um exemplo bastante evidente, já nos anos 30 Franz Boas mostrava como, além da disponibilidade lexical, as categorias gramaticais disponíveis em cada língua selecionam, classificam e exprimem diversos aspectos da experiência que devem ser expressos ou omitidos em uma cultura. Chamava a atenção, portanto, para um acervo de regras de organização das línguas que podem influenciar a maneira de exprimir as crenças, as manifestações poéticas e filosóficas em uma cultura e às quais os falantes da língua em questão devem adaptar-se. Em suma, para Boas, os processos gramaticais de cada língua carregam significações culturais que merecem estar sob a mira dos antropólogos. Em texto publicado em 1961, Jakobson atribui às descobertas de Boas nesse campo uma importante contribuição para a teoria linguística (JAKOBSON, 2008, p.87-97).

${ }^{3}$ Um exemplo da preocupação apontada por Philippe encontra-se no seminário organizado por James Clifford e George Marcus, em 1984, cujos principais resultados foram publicados em Wrigting culture: the poetics and politcs of ethnography, editado por ambos e a qual consultei na edição espanhola (1991).
} 
James Clifford (2002) sobre a escrita antropológica podem nos dar uma ideia de como os antropólogos têm enfrentado esse universo de questões. Ainda que a partir de perspectivas bastante distintas, ambos propõem uma mudança de atitude em relação à leitura dos textos clássicos da antropologia e uma nova percepção de seu ofício a partir da escrita. Seus trabalhos evidenciam simultaneamente o descentramento e a fragmentação do sujeito do conhecimento, os desvios inevitáveis da tradução, bem como, e talvez aí a novidade mais notável dessas análises, as estratégias narrativas de composição da escrita antropológica. Percebe-se de que modo os relatos antropológicos começaram a apontar o dedo para si próprios, marcando sua função de representação e evidenciando-se como co-produtores de sentido e não mais como janelas transparentes que dão a ver uma realidade diretamente transcrita no e do caderno de campo. Superando a confiança de certo regime realista de escrita, os antropólogos passam a compartilhar de dilemas comuns ao romancista contemporâneo, conscientes da insuficiência da linguagem e dos limites da representação, ainda que isso não queira dizer, claro, que sua tarefa seja a mesma.

\section{A antropologia especulativa saeriana}

As considerações acima não esgotam o potencial de aproximação dos antropólogos em direção à literatura, como pretendo demonstrar mais adiante. Antes disso, porém, e pensando na outra mão do caminho que me dispus a percorrer, como olhar para as relações que se estabelecem da literatura em direção à antropologia, especificamente no caso de Juan José Saer? Seria possível pensá-las por temas e imagens que alimentaram alguns de seus relatos mais conhecidos. Mas o objetivo aqui, como já anunciei, é estender a metáfora sugerida por ele: a literatura pensada como uma antropologia. Naquele que talvez seja seu ensaio mais conhecido, El concepto de ficción, Saer afirma que o relato de ficção, ao desprender-se das amarras do verificável, multiplica as possibilidades de enfrentamento das contradições que constituem o que chamamos de real. Por essa característica fundamental, diz ele, por suas intenções, por sua resolução prática e pela posição singular do ficcionista, situado entre os imperativos de um saber objetivo e as turbulências da subjetividade, seria possível definir de um modo geral a ficção como uma antropología especulativa (SAER, 2004, p.16).

Neste texto, ao apresentar a ficção como uma antropologia, Saer expõe as linhas mestras de sua própria poética. Opondo-se à ideia de literatura como mero entretenimento, o autor pensa a ficção como um mergulho nas turbulências da realidade, poderoso meio de conhecimento 
sobre o ser humano e sobre o mundo, daí sua dimensão antropológica.

O caráter especulativo da antropologia saeriana pode ficar mais evidente a partir da leitura que o autor faz de Roberto Arlt (SAER, 2004, 92). Na exploração da negatividade extremada vivida pelas personagens delirantes de Arlt, haveria uma pesquisa sobre os limites da condição humana, só possível por meio da experimentação de uma linguagem desprendida de sua função referencial.

A partir dessas breves referências, creio que seria possível explorar a ideia da antropologia especulativa em Saer por meio de duas questões fundamentais: a primeira diz respeito à maneira como o autor entende e explora os vínculos entre linguagem, realidade e representação e a segunda refere-se a uma das questões centrais na antropologia, a das relações entre o Mesmo e o Outro ${ }^{4}$.

Em relação à primeira questão, parece claro que Saer parte do pressuposto da autonomia da narração em relação a qualquer compromisso de representação: a narração poderia ser almejada como a criação de uma forma pura. No entanto, o autor afirma continuamente que a literatura almeja dizer algo sobre o real, mesmo admitindo antecipadamente a impossibilidade de fazê-lo. O fracasso reiterado da tarefa de representar faz com que cada escritor comece a tentativa sempre a partir de um novo começo, mas são essas tentativas que permitem ver de modo inédito algo sobre o mundo e sobre o ser humano, ideia que sublinha a dimensão antropológica que o autor enxerga na literatura.

Esse aparente paradoxo ganha relevo quando examinado à luz da polêmica que o autor estabeleceu com os escritores do Noveau Roman. A fortuna crítica em torno a Saer mostra como o autor comparte de uma série de afinidades e procedimentos com a narrativa identificada ao Noveau Roman, tendo sido inclusive tradutor de textos de Robbe-Grillet (La playa, 1967) e de Nathalie Sarraute (Tropismes, 1968) (RIERA, 2006, p. 57). Dentre tais procedimentos são evidentes a tensão entre o olhar e o mundo marcado pelas descrições objetivistas; a consciência de uma realidade fragmentada; as repetições com pequenas variações; a narração em um presente contínuo e a condensação temporal extremada. Florencia Abbate (2010, p. 79), contudo, afirma que embora haja uma proximidade de perspectiva, Saer sempre manteve certa distância em relação a alguns dos pressupostos que fundamentam a práxis narrativa do Noveau Roman, posição explicitada em Notas sobre el Noveau Roman e na polêmica estabelecida com

\footnotetext{
${ }^{4}$ No momento, tenhamos em vista a noção predominantemente filosófica da antropologia saeriana que aparece em seus artigos críticos. Mais adiante trabalharemos com a emergência de uma dimensão também etnológica no tecido de seus textos ficcionais e como leitor de Rosa.
} 
os autores da revista Tel Quel em Lingüística-ficción, ambos publicados em El concepto de ficción (2004, p. 170-178 e 179-182). Nestes dois artigos Saer não problematiza os romances de Robbe-Grilet, Nathalie Sarraute ou Butor, mas sim certo dogmatismo teórico que vê em seus textos críticos. Na questão que nos interessa agora, Saer não concorda, por exemplo, com a recusa prévia à representação, postulada por eles. Para o autor, ainda que a literatura seja um trabalho com a linguagem e com nada mais, e ainda que se reconheça o intervalo intransponível entre a representação e o referente - um problema com o qual cada escritor se defronta particularmente -, o trabalho encarniçado com as palavras é mobilizado por essa tensão dialética entre linguagem e mundo, no ponto em que ambos se confundem em um empastamento, como na pintura não figurativa ${ }^{5}$. Em sua concepção de linguagem, poderíamos aproximá-lo de Clarice Lispector quando ela afirma: "Tanto em pintura como em música e literatura, tantas vezes o que chamam de abstrato me parece apenas o figurativo de uma realidade mais delicada e mais difícil, menos visível a olho nu" (LISPECTOR, 1999, p. 316).

Vê-se portanto que, para Saer, a autonomia da palavra literária não significa uma dissociação com o mundo e sim o contrário: ela é um encontro com o mundo no ponto em que se fundem mundo e linguagem: "escribir requiere ante todo la operación de sumergirse en la pasta viscosa del mundo y del lenguaje" (SAER, 2004, p. 181). Não é à toa que ao criticar as propostas teóricas dos noveau romancières como uma espécie de transcrição sem mediações dos princípios da linguística geral, Saer cite a Sartre: "Sartre dijo una vez que se podría prescindir de la literatura pero que en ese caso se podría también prescindir del hombre”. Tratase de uma opção real, diz ele. Em alguma medida, essa ideia nos aproxima do sentido antropológico que Sartre também enxergava na experiência literária ${ }^{6}$.

Para Florencia Abbate, entre Sartre e os telquelistas, a posição de Saer quanto a uma teoria estética seria melhor definida talvez pela concepção adorniana de autonomia artística, que se afirma na medida em que são mantidos os laços entre a arte e o que lhe é heterogêneo (ABBATE, 2010, p. 81-82) ${ }^{7}$. De modo análogo, ainda que de outra perspectiva, poderíamos

\footnotetext{
${ }^{5}$ Dalmaroni (2010) evidencia como é importante e recorrente essa aproximação entre a linguagem e a pintura não figurativa na obra de Saer. Aliás, pontos de aproximação entre o autor e Lispector não se esgotariam a isso, como já evidenciaram alguns trabalhos críticos muito instigantes.

${ }^{6}$ Em seu projeto utópico de literatura em uma sociedade sem classes, dizia ele que a literatura viria a ser verdadeiramente antropológica na medida em que permitiria investigar em suas diversas manifestações a unidade indissolúvel da humanidade. (SARTRE, 1948/1993).

${ }^{7}$ Ainda assim, parece-me que o mais acertado seria mostrar a independência de Saer neste debate teórico, já que também não há uma coincidência plena entre as teses adornianas e a estética de Saer, no tocante, por exemplo, às questões do prazer estético. A forma como aparecem as posições bastante incisivas que ele assume em alguns
} 
entender a posição de Saer a partir da noção de metáfora viva de Paul Ricoeur, para quem a suspensão da referência no texto literário, sua autonomia, portanto, é a condição negativa que permite que seja liberado um modo mais fundamental de referência, uma inovação de sentido que faz vacilar e torna problemático o próprio sentido das palavras realidade e verdade $(\text { RICOEUR, 2005, p. 338-343) })^{8}$.

De todo modo, o que eu gostaria de ressaltar aqui é que em alguma medida a metáfora antropológica nos ajuda a entender a dimensão heurística da literatura para Saer, e essa ambição de um conhecimento sobre o mundo e sobre o ser humano, ainda que reconhecendo os limites e as dificuldades implicadas no trabalho com a linguagem.

Mas há uma segunda questão fundamental que sugeri explorar a partir da metáfora antropológica, e que diz respeito justamente às relações Mesmo/Outro, talvez a dimensão mais significativa do pensamento antropológico. Proponho examinar essa questão a partir de uma passagem de El río sin orillas, um tratado imaginário do autor sobre a formação da sociedade argentina a partir de sua relação com o Rio da Prata, ensaio no qual tais relações de alteridade se reconfiguram no tecido mesmo do relato, por um cruzamento inextrincável entre a perspectiva subjetiva do ensaísta (lembranças, percepções, afetos) e a busca de um olhar pela perspectiva do outro (os múltiplos relatos que o antecederam). Mas vale sublinhar um trecho em que essa dimensão antropológica que Saer enxerga na literatura é explicitamente tematizada. Ele começa com uma longa citação de uma carta de Flaubert:

\footnotetext{
"Es algo delicioso escribir. [Hoy he sido] hombre y mujer a la vez, amante y querida al mismo tiempo; estuve paseando a caballo en un bosque, en una siesta de otoño, bajo las hojas amarillas, y yo era los caballos, las hojas, el viento, las palabras que se decían y el sol rojo que les hacía entrecerrar los párpados ahogados de amor". (SAER, 2003, p. 210$)^{9}$
}

A essa citação de Flaubert segue-se uma digressão em que o ensaísta sentado à sombra de uma árvore, na prainha de um pequeno afluente de sua região natal, observa uma mulher que acompanha os netos em um banho de rio, enquanto levam um cavalo a beber água. Trata-se de um trecho do capítulo Primavera, quando o ensaísta aproxima-se de um ponto de chegada ao final do relato e quando justamente está refletindo sobre a literatura.

artigos não o impede de dialogar intertextualmente com autores de diversas concepções em sua obra de ficção, sem o prejuízo de dogmas assumidos previamente.

${ }^{8}$ Em Tempo narrado, volume III de Tempo e narrativa, Ricoeur prefere abandonar o vocábulo referência (em segunda ordem) por refiguração, explorando os vínculos que se estabelecem entre o mundo ficcional do texto e o mundo real do leitor por meio da mediação operada pela leitura (RICOEUR, 2010, v. III, p.270-271).

${ }^{9}$ Flaubert, não por acaso, disse em uma correspondência que praticava um "estilo canibal". (apud RIERA, 2006, p. 82). 
A observação da mulher e das crianças dá lugar a uma longa explanação a respeito das populações pobres habitantes das zonas marginais em pequenos povoados de todo o país. Tratase de um olhar do letrado que descreve e explica sociologicamente a formação e as condições de vida de comunidades historicamente excluídas dos benefícios do desenvolvimento econômico do país ao longo de sua formação. Contudo, as considerações sociológicas vão cedendo gradualmente a uma poderosa identificação do ensaísta com a mulher. Ele descreve sua aparência, seus movimentos discretos, e a empatia sutil estabelecida entre ambos a partir do gestual comum de cordialidade entre dois desconhecidos.

A mulher, provavelmente avó dos meninos, entra no rio levantando o vestido, esticandoo em um nó acima do joelho, deixando assim ver parte de suas pernas e acentuando as curvas do corpo sob o tecido. A sensualidade da cena não se traduz em um desejo pela mulher, mas sim, como em Flaubert, na possibilidade de habitar seu corpo:

\begin{abstract}
Cuando los pies de la mujer entraron en el agua, una sensación súbita de frescura, intensa y deliciosa, me recordó la existencia de los míos y los trajo al primer plano de mis sensaciones. (...) Yo experimentaba simultáneamente cada una de sus sensaciones y me costaba un esfuerzo sentir, por encima de ellas, las que en apariencia eran reales, es decir el contacto de las alpargatas secas que cubrían mis pies y la rugosidad seca del pantalón que rozaba mis piernas masculinas; el agua me ceñía hasta más arriba de las rodillas, y el ruedo mojado del vestido se pegaba contra mis propios muslos. (SAER, 2003, p. 217)
\end{abstract}

A especulação literária invadiu o registro da não-ficção e ampliou o universo investigativo do ensaísta. Por meio de uma projeção identificatória das sensações, ele se vê como a mulher, sentindo em suas próprias pernas o frescor da água que ela experimentava na pele, de modo que há uma "fusión momentánea que se produce entre la primera y la tercera persona, entre quien percibe y quien es percibida" (DALMARONI e MERBILHAÁ, 1999, p. 329). Após essa digressão, ele conclui que "el fin del arte no es representar lo Otro sino lo Mismo" (SAER, 2003, p. 219). Referindo-se a essa passagem, o crítico David Oubiña (2010, p. 185) agrega que Saer também poderia haver escrito que "el fin del arte es representar lo Mismo como lo Otro". Na cena acima, é somente por meio desse estar no outro, possível pela ficção, que o ensaísta consegue superar a distância do letrado para mergulhar na singularidade de outra vida. Evidencia-se assim o potencial de descobertas sobre a alteridade e sobre o si mesmo como categorias que a concepção saeriana de literatura relaciona entre si, como em um discurso antropológico.

$\mathrm{Na}$ entrevista a Gerard de Cortanze, também publicada em El concepto de ficción, Saer menciona novamente a experiência poética como um instrumento de conhecimento 
antropológico, desde que livre de qualquer compromisso de representação. Se em Proust, diz ele, é possível encontrar os traços históricos, culturais e sociais de sua época, por outro lado, os descobrimentos que realiza por meio de sua escrita alcançam uma dimensão antropológica, um conhecimento sobre humanidades de outros tempos e lugares, desde que haja leitores dispostos a lê-lo (SAER, 2004, p. 283). Por um lado, percebe-se mais uma vez a ideia de que é mergulhando na matéria singular e na concretude dos particulares que a literatura almeja um universal humano ${ }^{10}$. Por outro lado, destaco a figura do leitor como aquele que torna possível a mediação entre particularidades distintas. Ao esvaziar-se momentaneamente aceitando a voz de um outro, o leitor redescobre a si mesmo e vê seu próprio mundo de outra maneira.

Desenvolvo a seguir essa questão da alteridade experimentando a sobreposição de olhares de uma antropologia que se nutre da literatura e de uma literatura que se vê como antropologia, por meio do cruzamento dos textos do escritor, Saer, e do antropólogo, Eduardo Viveiros de Castro, na condição de leitores-escritores.

\section{O escritor e o antropólogo, leitores de Rosa}

Saer escreveu Mis tíos narradores originalmente como artigo para publicação em jornal e o mesmo foi posteriormente publicado no volume póstumo Trabajos (2006). O texto de Viveiros de Castro é parte de duas entrevistas, reunidas em livro e posteriormente sistematizadas em uma conferência tornada $\operatorname{artigo~}^{11}$. Talvez, rigorosamente, não sejam textos comparáveis. Reúno-os aqui na categoria um tanto arbitrária de exposições de leitura, cuja comparação me interessa na medida em que seus autores enunciam de seus campos específicos, motivados pelo mesmo conto de Guimarães Rosa, Meu tio o Iauaretê, de Estas Estorias (1969, p. $126-159)^{12}$.

No conto, um caçador de onças em seu rancho pobre e esquecido recebe um visitante

\footnotetext{
${ }^{10}$ Nesse sentido o autor parece retomar a perspectiva de Adorno em "Palestra sobre lírica e sociedade", texto no qual o filósofo aponta que é mergulhando no individuado que o poema lírico eleva-se ao universal humano, por tornar manifesto algo de ainda não subsumido ou acorrentado em um "universal ruim": "A composição lírica tem esperança de extrair, da mais irrestrita individuação, o universal” (ADORNO, 2003, p. 66).

11 "O perspectivismo é a retomada da Antropofagia oswaldiana em novos termos" (entrevista publicada originalmente em uma revista peruana de antropologia) e "Uma boa política é aquela que multiplica os possíveis". (CASTRO; SZTUTMAN (org.), 2008, p. 114-129 e 226-259). Algumas ideias desses artigos foram aprofundadas em "Rosa e Clarice, a fera e o fora" (CASTRO, 2018).

12 Antes da publicação em livro, o conto já havia sido publicado separadamente em uma revista em 1961. No entanto, em nota apresentada pelo próprio autor, sabemos que o conto é anterior a Grande Sertão: Veredas, de 1956.
} 
desconhecido, que busca abrigo para descansar e tentar recuperar-se de uma febre. A voz do narrador é a do onceiro em sua conversa com o recém chegado, de quem não ouvimos palavra durante todo o relato. Aos poucos, embalado pela cachaça, o onceiro desconfiado começa a revelar pormenores de sua história: mestiço de mãe índia e pai branco, ele havia crescido na aldeia da mãe, mas traíra seus parentes ao tornar-se caçador de onças: pela linhagem materna seu tio seria a onça Iauaretê. Certa noite, no entanto, confessa ele ao visitante, apaixonou-se pela onça Maria Maria, reconciliando-se com seu passado e com seus parentes índios. No relato entrecortado, em que as palavras do tupi-guarani vão cruzando o português mesclado do exonceiro, o narrador revela que havia ele mesmo se metamorfoseado em onça, sugerindo que como bicho já havia devorado cavalo e gente. O conto vai alimentando certo suspense e a tensão entre as duas personagens: o branco, cansado e com sono, segura sua arma e tenta não dormir para não ser morto, enquanto o índio anuncia os sinais de sua próxima metamorfose. O clímax final é congelado e apenas adivinha-se o desenlace com a vitória de um sobre o outro.

Para o antropólogo Viveiros de Castro, esse conto de Rosa é um verdadeiro momento de ruptura narrativa e metafísica da literatura brasileira (e latino-americana e mundial), comparável ao que representou a Metamorfose para a literatura europeia. Mesmo revelando as marcas da enunciação do antropólogo (2008, p. 245-246) ${ }^{13}$, ele evidencia na exposição de sua leitura um olhar para a literatura que vai muito além do uso estratégico da ficção na escrita e na análise antropológica. A meu ver, sua leitura supera inclusive a questão da consciência dos limites da representação entre os antropólogos, como apontei acima, ao permitir-se perguntar sobre o potencial de descobertas antropológicas que se realizam no âmbito mesmo e a partir da literatura. Eduardo Sterzi (2021, p. 214) mostra como a leitura do antropólogo, seguindo a trilha de leitura deixada por Haroldo de Campos, evidencia a complexa operação linguística, metafísica e política do conto que amalgama na própria linguagem a inquietação política e poético-antropológica posta em cena pelos personagens em diálogo em uma condição limite ${ }^{14}$.

\footnotetext{
${ }^{13} \mathrm{O}$ aparato conceitual da disciplina e da filosofia contemporânea que norteiam a leitura e a especulação metafísica aparecem como a maior evidência. Mas há marcas mais sensíveis do etnógrafo experiente, se quisermos arriscar: a suposição da malária na febre do viajante, por exemplo, o reconhecimento do tupi-guarani, a referência ao parentesco da onça como prima cruzada. A marca mais interessante, no entanto, é o entendimento que Viveiros e Castro apresenta da situação do narrador: supõe tratar-se do registro da fala do onceiro feito pelo visitante, quase como um caderno de campo. Na conferência/artigo ele revê essa hipótese e apresenta como mais incerta a posição do narrador (2018, p. 18). De fato, é difícil estabelecer ao certo a partir de que condição o narrador enuncia, pois toda a cena exterior à fala do ex-onceiro é apagada.

${ }^{14}$ Esse embaralhamento de fronteiras entre a literatura e a antropologia é assumido por Viveiros de Castro, neste artigo de 2018, como o ponto de partida de sua formação: primeiro vieram Oswald de Andrade, Guimarães Rosa, os tropicalistas, os irmãos Campos e Pignatari. Luiz Costa Lima teria lhe apresentado Lévi-Strauss. A antropologia
} 
Viveiros de Castro afirma que muito antes que os antropólogos começassem a se dar conta da teoria dos pontos de vista presente na compreensão indígena do mundo ${ }^{15}$, Guimarães Rosa já a experimentava ficcionalmente em Meu tio o Iauaretê. Vale a pena a leitura da cena do encontro na mata, quando o mestiço é acordado pela onça. O olho-no-olho, instante de máxima instabilidade nos mitos indígenas, lapso de tempo perigoso que dá margem às transformações entre humano e animal, aparece no conto como um enamoramento, verdadeiro renascer do personagem:

$\mathrm{Vi}$ aqueles olhos bonitos, ôlho amarelo, com as pintinhas pretas bubuiando bom, adonde aquela luz... (...) Olhos dela encostavam um no outro, os olhos lumiavam, pingo, pingo: olho brabo, pontudo, fincado, bota na gente quer munguitar: tira mais não. Muito tempo ela não fazia nada também. Depois botou mãozona em riba de meu peito, com muita fineza. Pensei - agora eu tava morto: porque ela viu meu coração tava ali. Mas ela só calcava de leve, com uma mão, afofado com a outra, de sossoca, queria me acordar. Eh, eh, eu fiquei sabendo... Onça que era onça. (ROSA, 1969, p. 396-397)

Para Viveiros de Castro, a presença mais poderosa do indígena na literatura brasileira é esse mestiço de branco e índia de nome africanado, Macuncôso, registrado microscopicamente em seu devir-anima ${ }^{16}$. Em verdade, segundo ele, assiste-se no conto a um duplo movimento de transformação, já que junto com o devir-animal do índio processa-se o devir-índio do mestiço "sua retransfiguração étnica por via da metamorfose", mutação que faz convergir dois movimentos opostos: a desalienação metafísica e a abolição física da personagem, no momento de sua morte sugerida ao final do conto. O antropólogo denomina esse duplo movimento de diferOnça, homenageando antropofagicamente os conceitos de Derrida e Deleuze (CASTRO, 2008. p. 128; 2018, p. 14), e mapeando os rastros da metamorfose do personagem na oncização mesma da língua ao longo do relato.

A teoria do perspectivismo pertenceria assim, ainda para esse autor, à mesma família política e poética da antropofagia oswaldiana, da qual Meu tio o Ianaretê seria o ponto

chegou depois e a experiência etnológica junto aos Araweté o devolveu à literatura novamente, em releituras posteriores de Oswald, Rosa e Lispector (CASTRO, 2018, p. 12).

${ }^{15}$ Tomo por base a teoria do perspectivismo ameríndio tal como desenvolvida por Viveiros de Castro em Perspectivismo e multinaturalismo na América Indígena (2011).

${ }^{16}$ Deleuze e Guatarri propõem pensar em devires-animais que atravessam homens e animais em uma aliança. Trata-se de uma espécie de involução criadora que arrasta o homem irremediavelmente para uma área de contágio animal. É nesse sentido que eles propõem uma releitura de casos clássicos da psicanálise como essa atração irresistível à rua ou à floresta, ao devir-cavalo ao devir-lobo, libertando os relatos da regressão doméstica ao triângulo edípico. A noção do devir-animal aparece na obra de Deleuze e Guatarri inspirada sobretudo da leitura da literatura moderna e contemporânea. Para eles, o escritor é esse feiticeiro que se deixa atravessar não por um devir-escritor, mas por devires-rato, devires-inseto, devires-lobo (p. 21). Ainda para os autores, toda forma de arte, cantar ou compor, pintar, escrever não teriam objetivo maior do que desencadear esses devires (p. 63), sejam eles o devir-mulher, o devir-criança, o devir-animal o devir-imperceptível (DELEUZE e GUATARRI, 2008). 
culminante, experiência perspectivista por excelência. No exercício desse estar no Outro por meio da língua, e colocando em cena dessa forma a cosmogonia indígena, o conto de Rosa promove um conhecimento antropológico por meio da antropologia do Outro, ou seja, mesclando-se à sua língua e expondo a forma como o Outro entende a humanidade e o mundo. Daí a filiação que o antropólogo estabelece com Rosa.

Interrompo no momento a leitura de Castro, para expor mais detidamente o texto de Saer. Lendo-o no conjunto de outros de seus ensaios de leitura, Mis tíos narradores pode ser visto como parte da exposição de uma biblioteca pessoal, que o autor desenvolveu ao longo de toda sua trajetória. Como afirma Ana Cecilia Olmos, a exposição das bibliotecas nos ensaios de leitura dos escritores de ficção é um meio pelo qual frequentemente eles deixam entrever as matrizes literárias de sua própria escritura, seja pelas afinidades que recortam, pelos contrastes ou desvios que estabelecem com e entre outros autores e obras (OLMOS, 2010, p.281).

No caso de Mis tíos narradores, é o tema mesmo da eleição da biblioteca que está em questão. Em primeiro lugar, já como fizera Viveiros de Castro, há certa desestabilização de um cânone tradicional ao fazer o conto ressoar alguns pilares da tradição ocidental, transcendendo o contexto brasileiro ou latino-americano. Na leitura de Saer, também em diálogo com o ensaio seminal de Haroldo de Campos, o ex-onceiro é emparentado ao Minotauro, meio homem, meio animal, atraído irremediavelmente pela aura de suas vítimas até receber a visita de um misterioso Teseu. Ao Minotauro, outros parentes são sobrepostos pelo autor: o bestiário onírico de Rosseau; Kafka; a literatura fantástica em sua vertente européia e platina.

Tematizando a eleição do parentesco literário, Saer aproxima a figura do ex-onceiro à de um narrador. Macuncôso desprendeu-se de sua fatalidade biológica, o pai branco, e escolheu reconhecer-se na linhagem do tio onça Iauaretê. Do mesmo modo, Dostoiévski superou a fonte inesgotável de problemas da ascendência paterna para inserir-se na filiação herdeira de Gogol, Balzac, Cervantes, Shakespeare e Homero. Não é preciso um salto muito grande no argumento para perceber que nesse texto curto em que convivem sem muitas mediações autores tão diversos como Kafka, Rousseau e Dostoievski, é evidente que Saer está expondo os seus próprios parentes eleitos: Guimarães Rosa é um de seus tios narradores.

Para além dessa declaração explícita, no entanto, é quando Saer evoca o tecido mesmo da prosa roseana que o parentesco faz-se texto, uma leitura desejante (BARTHES, 2010; OLMOS, 2010). Ao recordar os momentos poéticos que são para ele os mais intensos do conto, quando o ex-caçador descreve os animais, sublinha: 
una riqueza sensorial inusitada, menos por las evidentes asociaciones eróticas que por la variedad de sensaciones táctiles, olfativas, visuales, auditivas y aún gustativas, una diversidad de texturas y de colores en la descripción de la piel del jaguar, y una prosa fluida, blanda y elástica a la vez para expresar sus movimientos (...). (SAER, 2006, p. 75)

Como não ver aqui, nesse registro dos índices de percepção mais elementares, no fluir lento e elástico da prosa do outro, as marcas de sua própria poética: a expressão de seu desejo de escrita espraiando-se no corpo das onças de Rosa?

A leitura desse artigo acaba assim por inspirar a investigação da metáfora antropológica por um novo caminho, fazendo-a refratar a divisão clássica da antropologia e da etnologia, que vim ignorando até aqui. Se a antropologia pode ser caracterizada por sua ambição metafísica, por um amor pelo conceito e pela especulação (auto)contemplativa que a aproxima da sistematização filosófica, a Etnologia, ao contrário, tem seu olhar atraído inelutavelmente pelo objeto, privilegiando as situações vividas, submergindo-se no detalhe, na descrição minuciosa da materialidade do outro (CASTRO, 2008, p. 88; BALANDIER, 1977, p. 148-150). Talvez por isso, Barthes fizesse referência ao discurso etnológico como o mais próximo de uma ficção: "É que o livro etnológico tem todos os poderes do livro amado: é uma enciclopédia que anota e classifica toda a realidade, mesmo a mais fútil, a mais sensual” (BARTHES, 2003, p. 98). Nesse sentido, a forma como Saer lê a prosa de Guimarães é especialmente interessante para ser projetada sobre o narrador saeriano, que transita o tempo todo entre o mergulho etnológico no concreto e a divagação metafísica do antropólogo.

Inevitável pensar no exemplo tão evidente, neste caso, de El entenado (2004b). Gostaria apenas de contrastar duas passagens que podem ilustrar a alternância do duplo registro etnológico e antropológico, como sugeri, na escrita de Saer. Nesse romance, talvez o mais conhecido dos leitores brasileiros do autor, um jovem órfão participa como grumete de uma expedição ao Novo Mundo. Ainda que os dados referenciais não estejam presentes na narrativa, o relato alude à viagem empreendida em 1515 por Juan Díaz de Solís, descobridor do Rio da Prata, morto com parte de sua tripulação sob o ataque de índios desconhecidos ao desembarcarem em uma pequena praia do rio Paraná Guaçu. Do massacre os índios pouparam um jovem grumete, Francisco del Puerto, resgatado dez anos depois pela expedição de Sebastián Gaboto, segundo as crônicas.

Em El entenado, a narrativa se dá justamente do ponto de vista desse grumete parcamente documentado pelas crônicas. É ele o narrador que recorda os dez anos vividos entre os índios colastiné, até seu resgate pelos espanhóis que voltaram para dizimar essas populações 
durante o processo de conquista e ocupação da região. De volta à Europa, o ex-grumete foi acolhido em um mosteiro onde encontrou o padre Quesada, um pai espiritual que com amor e paciência the ensinou a ler e a escrever, franqueando-lhe um caminho pela música silenciosa dos livros. Após a morte do padre, o enteado abandona o convento e acaba por integrar-se a uma trupe de teatro mambembe na qual atuará representando o seu próprio papel na peça, criada a partir de suas aventuras como desterrado. Depois de alguns anos perambulando por cidades e vilarejos de toda a Europa, o grumete abandona a trupe levando consigo as crianças da companhia, órfãs de uma das atrizes, que fora assassinada. $\mathrm{O}$ enteado então se estabelece em uma vila mediterrânea, onde passa a viver de uma pequena imprensa com a ajuda dos filhos e agregados. A história é contada pelo ex-grumete já velho, que busca um significado para a sua vida na medida em que medita sobre os índios e sobre os sucessivos nascimentos pelos quais passou.

A primeira passagem para a qual chamo a atenção é o relato impressionante do primeiro ritual antropafágico presenciado pelo grumete logo em seus primeiros dias junto aos colastiné ${ }^{17}$. O narrador demora-se nos pormenores de cada minuto de todas as etapas do festim, ora aproximando-se e transitando entre os indígenas ansiosos reunidos em torno à fogueira, ora distanciando-se um pouco, mas observando ainda em ângulo fechado as expressões dos rostos, os olhares, os movimentos das mãos, a mastigação, os filamentos de carne humana que tragam de mordida em mordida. A mesma riqueza de detalhes prossegue na descrição do ritual orgiástico que se segue ao consumo da carne e da bebida alcóolica: a coreografia dos corpos, o suor, os ruídos. Ao final, descreve a perturbadora autoflajelação a que se submetiam os indígenas e o sangue que escorre das feridas após o transe extenuante e violento.

Nessa primeira narração do rito antropofágico o enteado parece refém da profusão dos pormenores que descreve em retrospectiva. Não se aventura a formular hipóteses ou explicações. Ao contrário, ao rememorar aqueles acontecimentos ocorridos havia mais de quarenta anos, o narrador busca representá-los a partir dos índices mais elementares de sua percepção, tal como os pode recordar. A reiteração dos detalhes, porém, ao invés de franquear um acesso à compreensão de todo o narrado, parece reforçar a precariedade dos fundamentos em que se sustenta a representação do outro. A alteridade radical com que se defrontava o grumete recém-chegado ao Novo Mundo permanece, assim, incognoscível (RODRÍGUEZ,

\footnotetext{
${ }^{17}$ A descrição de todo o ritual, desde os preparativos até o anti-clímax, extende-se ao longo de quase trinta páginas. Na edição citada, p. 48-76.
} 
Porém, apesar da distância intransponível entre o grumete e os índios, o estranhamento profundo em relação ao que testemunha acaba por abarcar ao próprio observador que, desconcertado, descobre em sua própria boca a saliva estimulada pelo cheiro da carne humana que queima na fogueira. O Outro encontra sua morada no interior do Mesmo; o Mesmo descobre-se tão inacessível e incompreensível como um Outro ${ }^{19}$.

Mas há uma segunda passagem do romance em que o narrador voltará a debruçar-se sobre o ritual descrito no início. Trata-se do trecho ao final do romance, quando se esclarece o papel de narrador e tradutor que os índios haviam lhe conferido, e que dá sentido à sua vida. Nessa segunda passagem, a lembrança dos colastiné dá margem a uma longa digressão filosófica, quando o narrador os compreende à luz de sua própria trajetória órfã e errante, precariamente significada pelas palavras que desenha com sua mão trêmula ao final da vida. $\mathrm{O}$ rito imperioso e avassalador ao qual a tribo se entregava reiteradamente a cada verão dá lugar a uma série de especulações: seria, quem sabe, uma tentativa de dominarem a memória de um passado arcaico de indistinção em que devoravam uns aos outros e de conferirem alguma materialidade ao mundo frágil que expressavam em sua língua hesitante (os verbos ser e estar, exemplifica o narrador, não existiam entre os colastiné, que dispunham apenas do verbo parecer para referirem-se à presença dos seres e das coisas). Os colastiné, como o narrador, percebiamse no ponto incerto de fusão das palavras com o mundo (SAER, 2004b, p. 149-160) ${ }^{20}$.

Os estudos genéticos coordenados por Julio Premat (2010, p. XLIII) trouxeram à luz o fato de que o primeiro projeto da escrita de El entenado era constituído pela ideia de elaborar

\footnotetext{
18 Amy Fass Every mostra como na tradição filosófica ocidental, pelo menos de Hegel a Sartre e Lacan, a relação eu/outro foi correntemente articulada em termos do desejo do eu por um outro que elude sua compreensão, um outro cuja irremediável diferença produz um desejo que, frustrado, pode converter-se em violência. Mas a escrita antropológica é ela também uma tentativa de apossar-se de um outro que não pode ser apreendido. Há, portanto, uma relação inextrincável entre desejo, linguagem e imaginação antropológica. Every lê nessa chave o conto de Clarice Lispector, A menor mulher do mundo, como uma metáfora da natureza predatória da atração do eu pelo outro e da antropologia como um discurso canibalístico e é nesse sentido que a autora aproxima Lispector e Saer, na medida em ambos associam o impulso antropológico da escrita à ingestão ritual do outro (EMERY, 1996, p. 110-113).

${ }^{19}$ Teríamos aqui novas possibilidades de encontro entre o escritor e o antropólogo como leitores, na medida em que dentre os diálogos intertextuais de El entenado reconhecemos a forte presença de Hans Staden, que Viveiros de Castro (2018, p. 20) apresenta como um ancestral dos autores antropofágicos de nossa literatura.

${ }^{20}$ Importante salientar que não há uma teoria pré-concebida da Antropofagia para "explicar" os colastiné de El entenado. O próprio Saer fez questão de afastar qualquer tentativa de substancializar uma teoria extratextual da antropofagia desses índios fictícios: "Todo en El entenado, si no es invención, no corresponde a ningún verdadero sistema, ni etnológico, ni lingüístico, ni nada. Hay contradicciones deliberadas, por ejemplo: el sistema de lo crudo y de lo cocido de Lévy-Strauss no funciona ahí”. Em entrevista a Linenberg-Fressard (apud CORBATTA, 2005, p. 59).
} 
ficcionalmente quatro conferências sobre uma tribo desconhecida. Deste projeto, a parte final do livro, que abandona o fluxo narrativo para estender-se em uma reflexão antropológica deve certamente a esse projeto original de especulação sobre uma tribo da qual só restou o nome.

Paulo Cesar Thomaz chama a atenção para a incorporação do debate filosófico e antropológico da contemporaneidade à explicação final que o narrador atribui ao ritual, ainda que a ótica ficcional se sobreponha às diretrizes positivas dessas disciplinas, uma vez que o autor apaga deliberadamente as distâncias entre esses discursos e a literatura, em um "amálgama de pactos textuais subvertidos nas estruturas e formas pelo caráter ficcional e dubitativo do romance" (THOMAZ, 2001, p. 130-131).

Como no conto de Guimarães Rosa, a figura desse narrador que transita por diferentes pontos de vista, por diferentes registros discursivos e por diferentes temporalidades, materializa na escrita o desejo exploratório sobre a materialidade de um Outro/Mesmo inventado na língua, permitindo o questionamento mais amplo de visões de mundo estabelecidas como únicas e de significados assumidos como realidades a priori.

Talvez agora seja possível, finalmente, retomar a Viveiros de Castro para ensaiar novas projeções de olhares entre ele e Saer. Sugiro pensar que do cruzamento de suas respectivas leituras de Guimarães Rosa evidencia-se a figura híbrida do escritor-antropólogo: solitário, estrangeiro sempre, metido numa selva espessa, explorando as (im)possibilidades de uma língua que lhe será sempre estranha nesse ambiente: a sua própria. Enfrentando os limites do já dito, ele escreve formas novas de vida, significações inéditas, gestos inesperados que desafiam seu poder de explicação, que desestabilizam os automatismos de seu próprio pensamento e desnaturalizam os códigos cristalizados pelo uso e pela norma de sua tradição. No mesmo lance, promove o reconhecimento de si mesmo em outras formas de existência, na alteridade da língua, alargando o horizonte dos possíveis de sua humanidade e dando a ver o potencial de sua liberdade.

Se, por um lado, são evidentes as diferenças do lugar de onde Saer e Viveiros de Castro enunciam suas leituras do conto, por outro lado, o escritor e o antropólogo acabam por convergir na condição de leitores desejantes a partir da qual buscam uma filiação, um tio narrador, e expõem suas descobertas sobre a literatura e sobre o ser humano. Como leitores, reconhecemse ambos na voz do mestiço virando índio, virando bicho: são primos, dois sobrinhos do Iauaretê e apaixonados pela onça Maria Maria. 


\section{REFERÊNCIAS}

ABBATE, Florencia. La posición estética de Saer. Crítica Cultural=Cultural Critique, v. 5, n. 2, p. 357-365, jul./dez. 2010.

ADORNO, Theodor W. Palestra sobre lírica e sociedade. In: ADORNO, Theodor W. Notas de literatura I. São Paulo: Duas Cidades/Editora 34, 2003, p. 65-89.

BALANDIER, Georges. Etonografia, Etnologia e Antropologia. In: GURVITH, Georges (org.) Tratado de Sociologia I. v. I, São Paulo: Martins Fontes, 1977, p. 148-150.

BARTHES, Roland. Roland Barthes por Roland Barthes. São Paulo: Estação Liberdade, 2003.

BARTHES, Roland. Escritores e escreventes. In: BARTHES, Roland. Crítica e verdade. São Paulo: Perspectiva, 2003, p. 31-39.

BARTHES, Roland. Da leitura. In: BARTHES, Roland. O rumor da língua. São Paulo: Martins Fontes, 2004, p. 30-42.

CASTRO, Eduardo Viveiros de. Rosa e Clarice, a fera e o fora. Revista Letras, n. 98, jul./dez. 2018, p. 9-30.

CASTRO, Eduardo Viveiros de; SZTUTMAN, Renato (Org.). Eduardo Viveiros de Castro. Rio de Janeiro: Beco do Azougue, 2008.

CASTRO, Eduardo Viveiros de. Perspectivismo e multinaturalismo na América Indígena. In: CASTRO, Eduardo Viveiros de. A inconstância da alma selvagem. São Paulo: Cosac Naify, 2011, p. 345-399.

CLIFFORD, James. A experiência etnográfica - antropologia e literatura no séc.XX. Rio de Janeiro: UFRJ, 2002.

CLIFFORD, James; MARCUS, George. Retóricas de la antropologia. Madrid: Ediciones Júcar, 1991.

CORBATA, Jorgelina. Presencia del canibalismo en El entenado de Juan José Saer. In: CORBATA, Jorgelina. Juan José Saer - arte poética y práctica literaria. Buenos Aires: Corregidor, 2005, p. 47-68.

DALMARONI, Miguel. El empaste y el grumo - narración y pintura en Juan José Saer. Crítica cultural=Critique cultural. v. 5, n. 2, jul./dez. 2010, p. 129-143.

DALMARONI, Miguel; MERBILHAÁ, Margarita. "Un azar convertido en don" - Juan José Saer y el relato de la percepción. In: JITRIK, Noé. Historia crítica de la literatura argentina, v. 11. Buenos Aires: Emecé, 1999, p. 321-343.

DaMATTA, Roberto. Relativizando - uma introdução à antropologia social. Rio de Janeiro: 
Rocco, 1987.

DELEUZE, Gilles; GUATARRI, Félix. 1730 - Devir-intenso, devir-animal, devirimperceptível... In: Mil platôs - capitalismo e esquizofrenia, v. 4. São Paulo: Editora 34, 2008, p. 11-113.

EMERY, Amy Fass. Sa(l)vage ethnography - the cannibalistic imagination in Juan José Saer's El entenado. In: EMERY, Amy Fass. The anthopological imagination in Latin American literature. Columbia: University of Missouri Press, 1996.

GEERTZ, Clifford. Obras e vidas - o antropólogo como autor. Rio de Janeiro: UFRJ, 2005.

JAKOBSON, Roman. A concepção de significação gramatical segundo Boas. In: JAKOBSON, Roman. Linguística e comunicação. São Paulo: Cultrix, 2008, p. 87-97.

OLMOS, Ana Cecília. Disponer y exponer la biblioteca - el ensayo de lectura de los escritores de ficción. In: MAIZ, Claudio (Org.). El ensayo latinoamericano. Mendoza: Facultad de Filosofia y Letras UnCuyo, 2010, p. 281-289.

OUBIÑA, D. El fragmento y la detención. Literatura y cine en Juan José Saer. Crítica cultural $=$ Critique cultural. v. 5, n. 2, jul./dez. 2010, p. 175-187.

PHILIPPE, Gilles. Fiction et argumentation dans l'essai. In: GLAUDES, Pierre. L'Essai: métamorphoses d'un genre. Tolouse: Presses universitaires du Mirail, 2002, p. 63-82.

PREMAT, Julio. Introducción. In: SAER, Juan José. Glosa / El entenado - edición crítica. Córdoba: Alción Editora, 2010.

RICOEUR, Paul. A metáfora viva. São Paulo: Loyola, 2005.

RICOEUR, Paul. Tempo e Narrativa. v. 3. São Paulo: Martins Fontes, 2010.

RIERA, Gabriel. Littoral of the letter. Saer's art of narration. Lewisburg: Bucknell University Presses, 2006.

RODRÍGUEZ, Susana Alicia A. Cartografía de una lectura: la percepción y la representación de la alteridad en El entenado de Juan José Saer. In: RODRÍGUEZ, Susana Alicia A. Abordajes y perspectivas 2. Salta: Ministerio de la Educación. Secretaría de Cultura de la Provincia de Salta, 2004.

ROSA, João Guimarães. Estas Estórias. Rio de Janeiro: José Olympio, 1969.

SAER, Juan José. El concepto de ficción. Buenos Aires: Seix Barral, 2004.

SAER, Juan José. Lingüística-ficción. In: SAER, Juan José. El concepto de ficción. Buenos Aires: Seix Barral, 2004, p. 179-182.

SAER, Juan José. El río sin orillas. Buenos Aires: Seix Barral, 2003. 
SAER, Juan José. Entrevista a Gerard de Cortanze. In: SAER, Juan José. El concepto de ficción. Buenos Aires: Seix Barral, 2004, p. 282-292.

SAER, Juan José. Mis tíos narradores. In: SAER, Juan José. Trabajos. Buenos Aires: Seix Barral, 2006, p. 73-77.

SAER, Juan José. El entenado. Buenos Aires: Seix Barral, 2004b.

SAER, Juan José. Notas sobre el Noveau Roman. In: SAER, Juan José. El concepto de ficción. Buenos Aires: Seix Barral. 2004, p. 170-178

SARTRE, Jean Paul. Qué é a literatura? São Pulo: Ática, 1993.

STERZI, Eduardo. Uns índios (suas falas). DasQuestões, v. 11, n. 1, abril de 2021. p. 210-233.

THOMAZ, Paulo César. El entenado - práxis poético narrativa de Juan José Saer. 2001.

(Mestrado em Letras) - Faculdade de Filosofia Letras e Ciências Humanas, Universidade de São Paulo, São Paulo, 2001.

Artigo submetido em: 05 ago. 2021

Aceito para publicação em: 24 out. 2021

DOI: https://dx.doi.org/10.22456/2238-8915.117444 